\title{
Encomiástica cristiana en la Historia de Jaén, de Jiménez Patón y Ordóñez de Ceballos
}

\author{
Christian encomium in la Historia de Jaén, \\ by Jiménez Patón and Ordóñez de Ceballos
}

\author{
Juan C. GONZÁLEZ MAYA \\ Departamento de Filología Española, Moderna y Clásica \\ Universitat Illes Balears \\ j-c.gonzalez@uib.es
}

\begin{abstract}
La Historia de Jaén (1628) is one of the lesser known texts that circulated under the name of the renowned humanist from La Mancha, Bartolomé Jiménez Patón. In this article, I study the controversy surrounding the book's authorship, and its attribution to Pedro Ordóñez de Ceballos. I also insert the text within the laus civitatis encomiastic tradition, and in the religious panegyric, as one more ingredient in the counter reformation discourses of the Spain of that period. Nevertheless, given the extension of the volume, my contribution strictly refers to the study of the formulas used by the authors in order to praise the distinguished men who carried out a significant part of their work in the old kingdom of Jaén. I conclude by summarizing some narrative techniques that are characteristic of fictionalized panegyric.
\end{abstract}

Keywords: Jiménez Patón, Ordóñez de Ceballos, Jaén, laus civitatis, laudis formula, encomiastic
Resumen: La Historia de Jaén (1628) es uno de los textos más desconocidos que han circulado a nombre del célebre humanista manchego Bartolomé Jiménez Patón. Estudio en este artículo su discutida paternidad con el clérigo aventurero de Jaén, Pedro Ordóñez de Ceballos, verdadero primer autor del libro; e inserto el texto en el género corográfico, la tradición encomiástica de la laus civitatis cristiana y en la del panegírico religioso, como un ingrediente más del discurso contrarreformista de la España de la época. No obstante, dada la extensión del volumen, mi aportación se ciñe al estudio de las fórmulas que emplearon los autores para establecer el elogio de ilustres varones que desarrollaron parte significativa de su labor en el antiguo reino de Jaén. Concluyo con algunas técnicas narrativas propias de panegírico novelado.

Palabras clave: Jiménez Patón, Ordóñez de Ceballos, Jaén, corografía, laus civitatis, formula laudis, encomiástica.

\section{PRELIMINAR}

El presente trabajo se inscribe dentro de un proyecto más amplio de recuperación de la obra no lingüística inédita del maestro Bartolomé Jiménez Patón (1569-1640), que venimos acometiendo desde la Universidad de las Islas Baleares. Desde hace ya unos años, se han editado y estudiado desde una perspectiva interdisciplinar (filológica, literaria, religiosa) varios de los textos no filológicos del ilustre humanista manchego. 
Este artículo, pues, se incluye en este ámbito y pretende arrojar algo más de luz sobre uno de los libros más curiosos en los que participó, alejado de sus inquietudes intelectuales y, en cierta medida, polémico, como veremos a continuación. Se trata de la Historia de la antigua y continuada nobleza de la ciudad de Faén, muy famosa, muy noble y muy leal guarda y defendimiento de los Reinos de España. $Y$ de algunos varones famosos, hijos della, impreso en Jaén por Pedro de la Cuesta en 1628, empezada por Pedro Ordóñez de Ceballos y terminada y corregida por Bartolomé Jiménez Patón. El libro es una suerte de miscelánea donde destacan primordialmente dos partes: una primera sobre la historia, geografía, costumbres, leyendas y monumentos de la ciudad y diócesis del antiguo Reino de Jaén; y una segunda centrada, como manifiesta el título, en sus hijos ilustres, clérigos y laicos, prelados y nobles, siguiendo un perfil más religioso, es decir, como elemento definidor de una identidad territorial. Es esta última parte la que más nos interesa ahora, también porque en la doble autoría del libro participaron probados hombres devotos ${ }^{1}$. No me detendré en las otras secciones del libro, asunto este de un estudio mayor que estoy preparando para una futura edición.

Así, pues, antes de pasar al objeto de estudio, la encomiástica cristiana de ilustres hombres de Jaén en el primer tercio del siglo XVII, se hace necesario contextualizar el libro en su tradición literaria, religiosa y corográfica. Para ello empezaremos introduciendo algunas consideraciones sobre el posible género en el que se inserta, para a continuación analizar algunas de las fórmulas y recursos más notables que lo identifican con una determinada tradición. Acabaré, finalmente, con unas breves palabras sobre la discutida doble paternidad y la relación de los autores con el proyecto.

\section{CONTEXTOS}

La Historia de la antigua y continuada nobleza de la ciudad de faén fue escrita y publicada en una época, el primer tercio del siglo XVII, en la que confluyen varias importantes tendencias históricas, sociológicas, literarias y religiosas que conforman y determinan su estructura, explicando su razón de ser.

1 Jiménez Patón fue ordenado de menores (de 'corona') pero no ejerció como clérigo. Además, ofició como notario del Santo Oficio en Murcia (1616). Ordóñez de Ceballos, auténtico trotamundos, evangelizador en América y Asia, en cambio, sí llegó a ser sacerdote (ca 1590). En 1616 fue nombrado canónigo de la iglesia de Astorga; y, alrededor de ese año, consiguió su nombramiento más importante, el de provisor, juez y vicario general «de todos aquellos reinos» («Cochinchina, Champaá, Cicir y los Laos y sus circunvecinos», f. 215 del libro). 
En primer lugar, el intento de la monarquía austriaca por demostrar las grandezas de sus territorios como un arma propagandística más (al igual que la pintura o la arquitectura), bajo cuyo amparo se desarrolló entre otros frutos, un mecenazgo de no pocos concejos de villas y ciudades o gobernantes, quienes competían por mostrar al mundo su esplendoroso legado: las gestas de sus ilustres ciudadanos, su significación en la Reconquista, sus valiosos tesoros artísticos y monumentales, su privilegiada geografía, su piedad o sus servicios y lealtad a la corona, entre otros, conformando una relación de hechos que hoy consideraríamos más apasionada que objetiva. En fin, elementos todos que dan unidad a una patria, y que no resultaban ajenos a la obra de Jiménez Patón tal como reflejó en el ámbito lingüístico en su Elocuencia española en arte (1604), siguiendo la estela de Gregorio López Madera en sus Excelencias de la monarquía y reino de España $(1597)^{2}$; y que más tarde retomaría su amigo Quevedo en La España defendida de los tiempos de abora y de las calumnias de los noveleros y sediciosos de Quevedo (16091612) $)^{3}$, identificándose de esta manera con la laus Hispaniae ${ }^{4}$.

En segundo lugar, el impulso renacentista al crecimiento y modernización de las ciudades, no solo españolas sino también europeas. Durante la primera mitad del siglo XVI signos de prosperidad económica y de cambio inundaron no pocas ciudades de la península. Bien sea por las nuevas demandas comerciales a nuevas necesidades, por la inmigración a centros urbanos, por el comercio exterior o los impuestos ${ }^{5}$, las ciudades se van desprendiendo paulatinamente de su aroma medieval para abrazar nuevos proyectos: diferentes grados de reformas urbanísticas, construcciones de iglesias, conventos, escuelas, hospitales o palacios a costa de la nueva oligarquía urbana, aproximándose así muchas ciudades a lo que Richard L. Kagan define como una auténtica edad de oro de la ciudad ${ }^{6}$.

En tercer lugar, y con la ayuda de la imprenta, todo este caudal de pundonor, satisfacción o grandeza, se canalizó a través de las vistas de las ciudades y, lo que más nos interesa, de la literatura, en la conformación de un género entonces novedoso como el de la chorographia, en la línea de los panegíricos humanistas de las ciudades

2 Jaume GaRaU, Portugal en la obra de Bartolomé fiménez Patón (1569-1640), en Hipogrifo, 3.2 (2015), p. 155.

3 Raimundo Lida fue el primero en tratar este asunto en «La "España defendida" y la síntesis pagano-cristiana», en Letras hispánicas. Estudios Esquemas, México, FCE, 1981, pp. 142-148.

4 Victoriano RONCERO, Las Laudes Hispaniae: de san Isidoro a Quevedo, en Analecta Malacitana, 13 (2003), pp. 81-92.

5 Richard L. KAGAN, «Ciudades del Siglo de Oro», en Ciudades del Siglo de Oro. Las vistas españolas de Anton Van den Wyngaerde, Madrid, El Viso, 1986, pp. 71-73.

6 Ibid., p. 79. 
italianas ${ }^{7}$. Nacida esta de la Geographia de C. Ptolomeo, alcanzó entre la segunda mitad del siglo XVI y primera del XVII su auténtico período de esplendor a tenor de la cantidad de libros publicados en esa época en toda Europa ${ }^{8}$. Como explicaremos a continuación, el término 'corografía' debe aquí entenderse como la suma de la descripción topográfica o geográfica y la histórica. A este factor determinante debemos añadir otra importante tradición centrada también en la valoración de lo local, esta desde un punto de vista encomiástico, que tenía su expresión en la laus civitatis o laus urbis, género también de importante raigambre y consideración?

En último lugar, que no de importancia, hay que citar las consecuencias de la reforma protestante y de la reacción de la Iglesia católica en el consiguiente concilio tridentino, que, no podemos olvidar, marcó un antes y un después en la historia cultural, que es la que ahora nos interesa, de nuestro país. Si partimos de la afirmación de Hubert Jedin de que «la Contrarreforma es la autoafirmación de la Iglesia en su lucha contra el protestantismo» ${ }^{10}$, nos re-

7 Aunque el panegírico de ciudades no es un invento de la literatura humanística, su desarrollo sí que influyó decisivamente en la literatura española de nuestro Siglo de Oro. Recordemos, en este sentido, la importancia del que quizás podríamos considerar el libro fundacional del género moderno, Laudatio Florentinae urbis (1402-04) del humanista italiano Leonardo Bruni, tradición continuada por Poggio Bracciolini y Lodovico Guicciardini, entre otros (ver España y la Italia de los humanistas: primeros ecos, de Ángel Gómez (Biblioteca Románica Hispánica, 382), Madrid, 1994, pp. 291295). Sobre la ciudad real e ideal del siglo xv italiano, se pueden consultar las consideraciones de Cesare de Seta en La ciudad europea del siglo XV al XX (colección Fundamentos, 208), Madrid, 2002.

8 Recordemos, por significativos, los casos del francés Joachim du Bellay (1522-1560) o del holandés Hugo Grotius (1583-1645).

9 Aunque exportado el término a otros escenarios y contextos, según Gómez Moreno, la laus urbis tenía su sentido en la Italia del Quattrocento, en el marco de las disputas entre las ciudadesestado (España... [ver n. 7], p. 291). Pero el género, lógicamente, es anterior, como nos recuerda E.R. Curtius (Literatura europea y Edad Media latina, México, FCE, 1976, pp. 228-229), con las poesías romanas medievales de las laudes Italiae y las laudes Romae; o los tratados de retórica epidíctica del retórico griego del siglo III d. C., Menandro el Rétor, donde en su libro tercero precisa «Cómo se debe hacer el encomio de una ciudad por sus actividades», con un buen número de implicaciones (Dos tratados de Retórica Epidíctica, ed. Fernando Gascó (Biblioteca clásica Gredos, 225), Madrid, 1996 (s. III d.C.), pp. 111-121 y 133-145). Y, acercándonos a nuestro territorio, con san Isidoro de Sevilla quien marca el punto de partida del panegírico dedicado a Hispania (Curtius, op. cit., p. 229), dando origen a todo un género, el de las laudes Hispaniae, en la introducción de su Historia de regibus Gothorum, Vandolorum et Suevorum (ca 624): De laude Spaniae, que continuaría el obispo Lucas de Tuy con su Chronicon mundi (ca 1236) y otros tantos cronistas y poetas medievales, que tuvieron su continuación en el Renacimiento con textos como los del humanista italiano Lucio Marineo Sículo (De rebus Hispaniae memorabilibus), ya como tema central de sus páginas (Roncero, Las Laudes... [ver n. 4], pp. 81-92).

10 H. Jedin apud Pierre-Antoine FABRE, «La época de la Contrarreforma política», en Discurso religioso y Contrarreforma, E. Serrano, A.L. Cortés y J. L. Betrán (coord.) (Institución Fernando el Católico), Zaragoza, 2005, p. 15. 
sultará natural que las disposiciones contrarreformistas requeridas por Roma, inundaran amplias parcelas de la cultura en virtud de esa «autoafirmación», poniendo de moda géneros de inspiración religiosa como la pintura, los grabados, las hagiografías, los devocionarios, breviarios, catecismos, relatos de milagros... o creando otros de nuevos como las comedias de santos, tan populares en la Comedia Nueva. Trasladado esto a la corografía, las páginas de estos libros se inundan de personajes locales que son auténticos ejemplos de virtud para sus conciudadanos por su trayectoria, encomiando acciones que, en algunos casos, llegan incluso hasta la santidad. Esto sin olvidar que las autoridades eclesiásticas financiaron muchos de los monumentos o reformas que luego se cantarían en los impresos. La religión alcanza, pues, un papel fundamental en la construcción del Estado ${ }^{11}$.

La Historia de la antigua y continuada nobleza de la ciudad de faén no puede entenderse, pues, sin este contexto en el que fue concebida. Ordóñez de Ceballos proyectó su libro en 1616, pero no se publicó hasta 1628, en tiempos de Felipe IV y de una fuerte presencia religiosa en las letras; es decir, que al tiempo que se propagaba la idea de una España imperial, con la misma fuerza se ponía todo el interés en la defensa de la fe católica. Por otro lado, también se aprovechó una base ideológica fundamental, que partía del auge de la religiosidad popular, muy significativa en Andalucía ${ }^{12}$, canalizada a través de toda suerte de formas populares del comportamiento religioso tan característico de la Iglesia postridentina, muy preocupada por estas expresiones tan externas: literatura, teatro o artes plásticas, por un lado; por otro, revitalización del culto a la Virgen, a los santos, a las reliquias, a las ceremonias, procesiones...

No debía de resultar complicado entonces adaptar esta tradición y volverla «a lo divino», cruzando elementos encomiásticos, a veces incluso épicos, y religiosos, sustituyendo el culto imperial o pagano del pasado por el sagrado; o asociando ciudades cristianas con la promoción de sus santos y hombres de fe. Surge así el interés por el desarrollo o promoción de urbes «religiosas» en sintonía con la curia romana y con el apoyo de las instituciones. La política del segundo Felipe de enfrentamiento y guerras de la Corona contra sus vecinos europeos y la

11 Carmen Delgado MORAL, Las fuentes cristianas en el Panegírico por la poesía: claves para una «Poética biblica», en Etiópicas, 10 (2014), p. 28.

12 Pedro CASTÓN BOYER, «Funciones sociales de la religiosidad popular en la sociedad rural y en la sociedad urbana de Andalucía», en M. J. Buxó, S. RODRíguEZ y L. C. ÁLVAREZ (coords.), La religiosidad popular I. Antropología e Historia (autores, textos y temas. Antropología, 18-20), Barcelona, 1989, p. 463. 
identificación que se consiguió entre monarquía y catolicismo, contribuyeron al suceso. Y este sí es un fenómeno renacentista.

De este contexto surgen las hagiografías de santos luchadores de las que tantas muestras tenemos en los diferentes géneros literarios, sobre todo en el teatro de la época (las comedias de santos). En nuestros encomios se revivirá ese espíritu militar donde todavía late el trasfondo de la Reconquista; o donde comprobamos cómo los guerreros o soldados de Cristo convierten su vida en una milicia constante, sirviendo en diferentes destinos y situaciones a una empresa común.

La exposición, pues, de las virtudes, atributos o los caminos de santidad recorridos por los hijos ilustres de estas ciudades, servían también para honrar sobremanera a sus «patrias» de origen, exaltando la religiosidad de sus pueblos o el papel desempeñado por las ciudades, en oposición incluso a otras urbes europeas bajo la reforma protestante. Al tiempo que contribuían a la creación de modelos en su lucha contra la «infección» herética o el maligno dentro del ámbito de una monarquía católica.

Así, pues, no podemos olvidar todo este conjunto de factores, porque son ellos los que definen, estructuran y alumbran un proyecto de naturaleza contrarreformista. Dejando, pues, ahora al margen los hechos históricos y los sociológicos, se hace necesario, antes del análisis que nos ocupa, unas palabras explicativas que nos acerquen con mayor precisión a los dos elementos que mejor definen la estructura de la Historia de faén: la chorographia y la laus civitatis.

\section{LA LAUS CIVITATIS CRISTIANA: EL REINO DE JAÉN}

La «grandeza»y la «nobleza» constitutiva del género, y que reflejan tantos títulos de estas obras, y la nuestra en particular, obedecía al intento de sacralizar un espacio, de cantar las excelencias de un lugar humano y físico, para mitificar su historia y celebrar su orgullo nacional. Hecho que relaciona nuestro libro con dos viejas tradiciones: la chorographia y la laus civitatis.

La primera de ellas, nacida como una mera observación de una realidad física concreta, ponía su acento en la descripción geográfica y monumental de un lugar, pero se actualizó en el Quinientos añadiendo a sus ingredientes básicos el conocimiento del pasado. Entendiendo por 'pasado', antigüedad, historia, costumbres y leyendas. La segunda, el elogio nacional, ensancha las visiones corográficas, amplificándolas con un componente nada despreciable para los propósitos de un proyecto de esta finalidad, y muy necesario para definir a una comunidad cristiana: la piedad y la virtud (cívica y religiosa) de los presentados como egregios y 
ejemplares ciudadanos. A ello deberíamos añadir los fatigosos y detallados capítulos dedicados a las genealogías nobiliarias características del género ${ }^{13}$, que, según R.L. Kagan «representa sobre todo la voz, el medio de expresión de las oligarquías urbanas que, en el proceso de la consolidación de sus poderes dentro de los ayuntamientos durante los siglos XVI y XVII, acudían a la historia como ayuda en esta tarea $\gg^{14}$. Ingredientes estos consustanciales al empleo que planteo de civitas o civitatis, en su acepción humana, término complementario de su hermano urbis, más corográfico, aunque sus límites no siempre sean tajantes.

Unimos así de esta manera, realidad física, ciudad, cristianismo y elogio, que, además de constituir una de las esencias del pensamiento español de la época, entrelazan los capítulos de nuestra Historia de faén, con el fin concreto de promocionar un lugar o una comunidad como un ente único y diferenciado de otros territorios peninsulares.

Pero dejando ya de lado la vertiente más corográfica, voy a ocuparme ahora de los capítulos donde el perfil humano, encomiástico y cristiano, es componente principa ${ }^{15}$. La valoración de lo local se ajusta aquí a nueve biografías de probados hombres de fe y con relevante proyección histórica o cívica. En sus trayectorias lo que interesa es detallar una serie de principios, espirituales o temporales, que por sí mismos eran capaces de hacer diferentes los valores de una tierra: el fervor religioso, el buen gobierno, el ejercicio de las armas y las letras... De esta forma se intentaba no solo preservar la memoria de los lugares por donde vivieron, sino también crear conciencia cristiana como guía para sus ciudadanos. De ahí que en la mayoría de los perfiles biográficos, estos pasan a un segundo plano en favor de sus obras pías, sus descubrimientos o acontecimientos y milagros varios de sus ejercicios como representantes de la Iglesia.

13 Doce capítulos dedicados, por este orden, a las casas de los condes de Villardompardo, condes de Bailén, marqueses de Jabalquinto, condes de Santisteban, marqueses de Jódar, marqueses de Bedmar, vizcondes de Huelma, condes de Garcíez y vizcondes de Santo Tomé, marqueses de La Guardia, condes de Alcaudete, marqueses de Camarasa y condes de Ricla; y casa de los señores de la Torre y Señorío de Valenzuela y casa de Acuña (caps. 25 bis, 27-36, 33bis; ff. 133-136 y 148193).

14 La corografía en la Castilla moderna: género, historia, nación, en AISO III, Toulouse, 1993, p. 89.

15 Son nueve capítulos de los 46 de que consta el libro. Este no se divide en partes ni en secciones, aunque sí se puede advertir cierta estructura: capítulos 1-9: antigüedad, piedad, descripción física y monumental de las ciudades importantes del antiguo Reino de Jaén; 10-11: obispado y Santo Sudario; 12-20: biografías y hechos relevantes de ilustres prelados y clérigos; 21-26: biografías de varones famosos nobles; 25 bis, 27-36: genealogías nobiliarias; 37: descripción de poblaciones menores con sus personajes ilustres; 38: biografía de Pedro Ordóñez de Ceballos; 39-46: arciprestazgos y construcciones religiosas. 
Jaén se postula de esta manera, tal y como preconiza el título, en una tierra «muy famosa, muy noble y muy leal guarda y defendimiento de los Reinos de España» ${ }^{16}$, propuesta que parece remitirnos al ámbito de la lucha contra el hereje o de las luchas europeas de religión, verdadero sustrato del libro, tomada aquí especialmente en su vertiente civitatis ya mencionada. Un ejemplo lo podemos comprobar en los esfuerzos de estos ilustres varones en la promoción, descubrimiento o traslado de valiosas reliquias o imágenes santas, que tanto podían servir para bendecir los territorios como para definir a sus ciudades como espacios representativos de culto o peregrinaje.

En este sentido, el episodio más destacable del libro es el del Santo Rostro de Jesús o Santo Sudario, o la Verónica, así como es llamado en los documentos de la época; reliquia de gran valor trasladada desde Roma a la catedral de Jaén en el siglo XIV por el obispo don Nicolás de Biedma (¿-1383, caps. 11 y 12) ${ }^{17}$, según la leyenda. Atribución hoy discutible, pero cuyo gran mérito radicó en que puso en circulación el nombre de la ciudad giennense en la órbita cristiana, convirtiéndola en ciudad de peregrinaje ${ }^{18}$. Se satisfacía así, además, una de las

16 No es este lema obra de los autores (aunque se cambia 'Castilla' por 'España'), sino el título que le concedió Enrique IV de Castilla a la ciudad posiblemente en 1466 (Boletín de la Real Academia de la Historia, tomo CLXXXVIII, cuaderno 1, 1991, p. 184).

17 Cap. 11: «Del santísimo Sudario de Cristo nuestro bien, que enriquece de fama y glorioso nombre a la ciudad de Jaén» (ff. 41-48); cap. 12: «Don Nicolás, obispo desta ciudad, que alcanzó del Sumo Pontífice esta inestimable reliquia» (ff. 48-51). Las versiones de cómo llegó el Santo Rostro a la catedral de Jaén varían según las fuentes o las leyendas consultadas (Rafael MASSANET, El santo rostro en la Historia de faén de Bartolomé fiménez Patón, en JISO (2012), pp. 263-273). A san Eufrasio, primer obispo de la Diócesis, también se le atribuye el mismo mérito (M. ${ }^{a}$ Amparo LóPEZ ARANDIA, Rinascimento y reformatio. El proyecto de Gutierre González en faén, Jaén, Universidad de Jaén, 2005a, pp. 465-466), aunque los autores lo descartan porque «... más se funda en piadoso afecto [...] que en discurso historial» (f. 50v). La reliquia se encuentra hoy custodiada en la Capilla Mayor de la catedral de Jaén.

18 Son numerosos los textos que inciden en ello. Lucio Marineo Siculo, en De rebus Hispaniae memorabilibus (1530), Libro V, 40-48, entre las «cosas» memorables de España destaca que Jaén: «no sin razón se vanagloria del sudario de Cristo, al que con otro nombre llamamos Verónica. En efecto, premiada con este santísimo regalo, aquella ciudad es muy dichosa, es muy rica, y es visitada por muchos y es sobremanera venerada» (José Ramón RIVERA MARTÍN, Estudio filológico sobre De rebus Hispaniae memorabilibus libri I-V de Lucio Marineo Sículo, Madrid, Universidad Complutense, 2000, p. 144). Más contemporáneo de Ceballos, Agustín de Rojas Villandrando también destaca la visita a la Verónica de Jaén en un diálogo de su Viaje entretenido (1603) (ed. Jean Pierre Ressot (clásicos Castalia, 44), Madrid, 1972, libro segundo, p. 202). Incluso Cervantes la menciona en Los trabajos de Persiles y Sigismunda (1617) (en Obras completas, Madrid, 1993, 4, libro tercero, p. 677); y Alonso de Castillo Solórzano, en las Aventuras del Bachiller Trapaza (1637) (ed. Jacques Joset, Letras hispánicas, 257, Madrid, 1986, cap. XIII, p. 217), entre otros. 
demandas del concilio tridentino sobre el culto de las imágenes sagradas ${ }^{19}$. En los dos capítulos dedicados a esta auténtica vera icon, los autores reconstruyen sus posibles orígenes, según la tradición, sus milagros y los avatares que dieron lugar a la aparición de otros santos sudarios con el fin de corroborar la autenticidad y primacía del de Jaén sobre los expuestos en Roma y Jerusalén (no se mencionan los otros lienzos que se custodian en la península: el del monasterio de la Santa Faz de Alicante; y el de la catedral de Oviedo). Esto sin dejar de remarcar en todo momento el papel fundamental del obispo Biedma en su recuperación.

En otras ocasiones se recurre a una dimensión más sobrenatural, capaz de turbar o mover las almas de los feligreses y favorecer su devoción. El capítulo dedicado a la Virgen de la Capilla, patrona de la ciudad de Jaén, y al famoso capitán y obispo don Gonzalo de Zúñiga, donde se cuenta la extraordinaria procesión celestial de la Virgen, que mudó su emplazamiento original en la catedral vieja por el de la iglesia de San Ildefonso, y cuya aparición fue providencial en la victoria contra los moros de Granada (1430), representa sobre todo un nuevo triunfo de la Cristiandad contra el hereje, a pesar de que los autores instrumentalicen la historia de España en favor de la historia sagrada, expresión entonces corriente.

Las noticias de la intercesión de la Virgen u otras instancias divinas en las luchas contra el Islam en la Península Ibérica son abundantísimas en la historiografía medieval, en tanto que auxiliadora de los cristianos en las fronteras o en la reconquista de las ciudades, hecho común en aquella cultura de signo providencialista. La intervención divina como respuesta a las súplicas ennoblecía, además, el espacio urbano y forjaba adhesiones y advocaciones.

Hay capítulos en los que, a pesar de estar dedicados a importantes prelados, el asunto central gira más en torno a la veneración de las imágenes sagradas, especialmente las de devoción mariana, en detrimento de las reliquias corporales. Veamos ahora el caso de la Virgen de la Coronada ${ }^{20}$, imagen de época visigótica, descripción cuya estructura o patrón sigue un modelo general, repitiéndose en otras figuras sacras: hallazgo de una santa imagen perdida (en realidad, según

19 Sesión XXV de 2 de diciembre de 1563: «La invocación, veneración y reliquias de los santos y de las sagradas imágenes» (Ignacio LópEZ DE AYALA, El Sacrosanto y Ecuménico Concilio de Trento, traducido al idioma castellano por---- . Con el texto latino corregido según la edición auténtica de Roma publicada en 1564, Barcelona, 1847, pp. 327-396).

20 Cap. 14: «De don Alonso Suárez de la Fuente el Sauce y de la Virgen de la Coronada y Hospital de san Antonio de Padua» (f. 57v). 
se cuenta, escondida por los godos cuando perdieron Hispania, f. 60) por parte de unos labradores; veneración, construcción de un lugar de culto; milagros o capacidad intercesora de la Virgen en la lucha contra el infiel ${ }^{21}$; devoción de la feligresía; institución de una cofradía («Los Ballesteros de la Coronada»); escudo contra los moros en defensa de la ciudad; ampliación de los lugares de culto (levantamiento de un convento); visiones del clero; apariciones y milagros ( $\ll \mathrm{La}$ noche siguiente volvió Nuestra Señora y le dijo: “¿Cómo no haces lo que te mando?"», f. 62); instauración de un día de fiesta... Estamos, pues, ante unas conocidas técnicas de elaboración y recursos que todo creyente, conocedor de otros materiales similares, conocía perfectamente.

El hallazgo de imágenes sagradas, al tiempo que ofrecían curiosas noticias sobre la Historia particular de las localidades, aseguraban nuevamente la presencia divina en sus tierras, creando espacios sagrados; legitimaba su veneración, porque podían ser favorables en las intercesiones divinas, asegurando la comunicación terrenal-celestial; promocionaba la ciudad, dándole prestigio y fama, convirtiendo sus imágenes sacras en su mayor tesoro. En este sentido, Andalucía brilló por encima de otros territorios por la abundancia de sus hallazgos: «dando cuenta que Dios la había elegido y el cielo la había bendecido y enriquecido» ${ }^{22}$.

Junto a estas imágenes o apariciones favorecedoras del culto, se erige simultáneamente la ciudad religiosa: la civitas Dei giennensi. En este apartado el libro destaca los esfuerzos de la comunidad religiosa en la construcción de una ciudad santa: catedrales, capillas, conventos, escuelas, hospitales, puentes... Es posible que en este punto los autores tuvieran presente alguna publicación contemporánea como la hagiografía de San Antonio de Padua (1604) de Mateo Alemán, donde en su capítulo $\mathrm{V}$ se toma el modelo católico de la ciudad de Lisboa con la descripción de sus monumentos religiosos: «Descríbese Lisboa y su sitio; refiérense algunas cosas de las dignas de alabanza en ella y en los de aquella nación ${ }^{23}$.

21 Rescate de cautivos cristianos en el Reino de Granada. En señal de agradecimiento se colgaron en las paredes de su templo los grillos y cadenas del cautiverio: «... hallándose a la mañana los moros sin esclavos y los cristianos libres y en presencia de la reina de los ángeles que les había negociado su libertad» (f. 60v). La redención milagrosa de cautivos es de amplia tradición medieval.

22 Andrea MARIANA NAVARRo, Los santos y el imaginario urbano en los discursos bistoriográficos: Andalucía siglos XIII-XVII, en Hispania Sacra, LXII (2010), p. 485.

23 En La obra completa 2, ed. Henri GUERREIRO y Marc ViTSE, Madrid / Frankfurt am Main, 2014. Tradición que seguiría El burlador de Sevilla, atribuido a Tirso de Molina, que ya estudió M. Vitse, como modelo de santidad (La descripción de Lisboa en El burlador de Sevilla, en Criticón, 2 [1978], pp. 20-41). 
Técnica esta que el propio Jiménez Patón había experimentado en su elogio a la ciudad de Lisboa en sus Comentarios de erudición ${ }^{24}$.

Los autores bien se encargan de demostrar que la santidad de algunos obispos se podía medir también por todo aquello que eran capaces de hacer en favor de sus feligreses, de peregrinos y viajeros, porque eran estos instrumentos de propagación de la fe. No puede considerarse este un asunto baladí. En los países católicos, la circulación de fieles por rutas de reliquias sagradas era abundantísima. Nada mejor para ello que la instauración de caminos o la mejora de algunas instalaciones que beneficiaran este tránsito. En ese cometido, el libro destaca la labor de don Alonso Suárez de la Fuente el Sauce (¿-1520), inquisidor general en 1594 y obispo de Jaén entre 1500 y 1520, también llamado el «obispo constructor». A su tesón debemos numerosas obras de entre las cuales se destacan especialmente dos muy significativas: la del Hospital de san Antonio de Padua (1528), hoy convento; y, sobre todo, el llamado Puente del Obispo, obra magna del primer Renacimiento hispano (1505-1508), que, en ese estilo hiperbólico tan del gusto barroco, llega a ser comparado con El Escorial o las pirámides de los faraones (f. 59). Amén de otras construcciones y mejoras en diferentes iglesias y catedrales durante el primer tercio del siglo XVI.

Podríamos continuar aquí con otros importantes prelados giennenses en la fundación de conventos, iglesias, capillas o colegios de teólogos, entre otras intervenciones, como la del citado Nicolás de Biedma en la construcción de la catedral gótica de Jaén (iniciada en torno a 1369); pero, por la relevancia del personaje, no quisiera pasar por alto la fundación de las escuelas de Baeza (1538), más tarde universidad (1542) por el «apóstol de Andalucía», san Juan de Ávila (1500-1569)25, uno de los predicadores más influyentes de la época; el «evangélico predicador y doctor», como es llamado por Ceballos-Patón. Triunfante del aparato inquisitorial y dentro de la retórica del elogio de su panegírico, su imagen representa el vínculo perfecto entre misión evangélica y laus civitatis, en su sentido de «ciudad cristiana», ennobleciendo así su espacio urbano.

La universidad de Baeza nació primero como escuela de primeras letras gracias al empeño del clérigo local Rodrigo López en 1538, familiar del papa Paulo III. Pero fue de la mano de Juan de Ávila cuando se convirtió en Univer-

24 Jaume GaRaU, Portugal... [ver n. 2], pp. 149-163.

25 Se puede consultar al respecto el capítulo La escuela de fuan de Ávila en Dolores Rincón-Raúl MANCHÓN (eds.), El maestro fuan de Ávila (1500?-1569). Un exponente del humanismo reformista, Madrid, 2014, pp. 523-672. 
sidad de Artes y Teología (1542) ${ }^{26}$, nombrado patrón perpetuo y administrador al efecto. También llamadas «Escuelas de la Santísima Trinidad», el libro destaca el importante papel del padre Ávila en su fundación, en la configuración de los estatutos y en una de sus preocupaciones fundamentales: encontrar un lugar para formar a los aspirantes al sacerdocio. Entre sus alumnos se distinguieron dos discípulos a los que se dedican sendos capítulos: Diego Pérez y Luis de Noguera. Sin embargo, el libro pasa de puntillas sobre la acusación de iluminado del Maestro Ávila ${ }^{27}$. En realidad, el planteamiento del capítulo es no entrar precisamente en detalles espinosos, sino mostrar el episodio como una intromisión más del maligno en las esferas de personas de probada rectitud, con maledicencias, falsas calumnias o envidias ${ }^{28}$, para concluir con un rotundo «... salió, como dicen del sol, después de nublado más claro, limpio, puro y hermoso» (f. 97).

\section{LA FORMULA LAUDIS GIENNENSI}

Como hemos visto, la estructura narrativa de este tipo de textos está basada en la retórica del elogio destinada a exaltar los valores religiosos, tanto del reino de Jaén como de sus ilustres moradores, con diferentes motivaciones: como agradecimiento a la tierra, como preservación de la memoria, como medio de expresión de la nobleza... o cualquiera de las comentadas al principio de este artículo. En cualquier caso, el empleo del pasado o el presente como expresión o prototipo de la Cristiandad emanada de Trento.

Y es aquí donde debemos situar los panegíricos de aquellos «claros varones» cuyas vidas ejemplares podían honrar o engrandecer las tierras andaluzas, situando así a Jaén en el mapa de la santidad en España. Para ello los autores seleccionaron en su libro nueve hombres (el primero de ellos muerto en 1383; el último, en 1595; sus historias se incluyen desde los capítulos 12 al 20 inclusive), célebres por su profesión de fe, no necesariamente nacidos en el reino de Jaén, pero que allí desempeñaron una parte significativa de su vida. La selección es muy particular

26 La tercera en importancia de Andalucía después de las de Sevilla y Granada.

27 Pasó cerca de dos años en la cárcel de Sevilla (1532-1533) por predicar doctrinas de «cierto sabor erasmista» (Francisco MARTÍN HERNÁNDEZ, ¿̨Fue erasmista san Fuan de Ávila?, en Anuario de Historia de la Iglesia, 21 [2012], p. 64). Efectivamente, se le acusaba de que lo que predicaba ante sus discípulos tenía cierto aroma erasmista o iluminista, no conforme a la fe católica.

28 Aquí podríamos deducir un paralelismo con el propio Ceballos, quien manifiesta haber sufrido también la envidia de sus contemporáneos. Ver n. 55. 
y no obedece a ningún criterio específico, salvo el interés o la sensibilidad de los autores, al hecho de que todos puedan ser considerados como auténticos símbolos de la identidad de un pueblo ${ }^{29}$, o quizás prevalezca el criterio de la limpieza de sangre, asunto sobre el que se incide a menudo ${ }^{30}$.

En la disposición de estos capítulos los autores contaban ya con una importante tradición tan antigua como las retóricas clásicas de Aristóteles o Quintiliano, con leves cambios debido a la materia:

- Orígenes: patria o ciudad (patria), familia (genus), precocidad

- Educación (educatio) - espiritualidad (spiritualitas), advocaciones

- Vida ejemplar (exemplum): viajes, habilidades y hechos

- Muerte: ejemplaridad del tránsito (martirio), pena (luctus)

Se plantea, pues, la encomiástica siguiendo un hilo hagiográfico-narrativo y cronológico, con la inclusión de muchos episodios legendarios, algunos no suficientemente acreditados, otros anecdóticos y otros directamente discutibles, con la intencionalidad manifiesta de este tipo de escritos: la de provocar la admiración del receptor, sea cierto o no lo que se cuenta, dentro de un marco providencialista de la Historia de España y de Jaén en particular.

Entre los nueve hombres de fe, distingo en mi estudio tres categorías según sus empresas. En la de los más lejanos en el tiempo, destaca el grupo de Bellatores Domini («obispos-soldados» u «obispos animosos», como los califican los autores), en su lucha contra el Islam. Aquellos que desde sus localidades andaluzas se convirtieron en elementos decisivos en la extensión de fronteras y, por consiguiente, en la formación y desarrollo de su patria (en su acepción de comunidad natal) y del Estado, por su afán de lucha contra el infiel. En estos casos nos encontramos con auténticos guerreros de la milicia cristiana, como don Nicolás de Biedma, capitán en el ejército, «terror y asombro de los enemigos de la fe cristiana» (f. 49); y sobre todo el belicoso don Gonzalo de Zúñiga (o Estúñiga) y

29 Llama la atención, en cambio, algunas ausencias significativas, como la del famoso D. Bernardo de Sandoval y Rojas, obispo de Jaén entre 1596 y 1599, contemporáneo de los loados y famoso por su protección a escritores como Fray Luis de León, Cervantes, Lope de Vega, Quevedo o Góngora; pariente cercano del duque de Lerma, valido de Felipe III, primado de España, consejero de Estado, inquisidor general...

30 Del mismo modo que en la corografía del Siglo de Oro se tenía mucho cuidado en no recordar el legado artístico-cultural-monumental musulmán o judío, en los encomios también se insiste una y otra vez en mostrar pasados limpios de toda impureza. En esta dirección conviene recordar que Patón fue un firme defensor de los estatutos de limpieza (Jaume GARAU, «No bay mayor desigualdad que hacerlo todo igual». Sobre el Discurso de Bartolomé fiménez Patón en defensa de los estatutos de limpieza, en Bulletin Hispanique, 114-2 [2012], pp. 597-620). 
Leyva (1390?-1457) ${ }^{31}$, más batallador que religioso, todo un personaje de leyenda, quien «con el valor de su espada aseguraba su ciudad, reino y ejército» (f. 53v); conocido por su intervención en numerosas operaciones militares ${ }^{32}$ fue, sin duda, de los retratados, la figura que más destacó en la lucha contra los musulmanes, motivo por el cual fue ampliamente celebrado, como así muestra toda una serie de leyendas, romances o coplas populares, que dan buena cuenta de su fogosidad, y que nos recuerda nuestro libro: «El obispo de Jaén / suele decir misa armado» (f. 53v), el Romance del Obispo don Gonzalo (f. 56) ${ }^{33}$ o el Romance de Reduán y el rey Chico sobre la conquista de faén (f. 55) ${ }^{34}$. En este retrato, como en otros tantos, los autores se dejan llevar por el entusiasmo en la mitificación de una legendaria figura sin reparar en las posibles contradicciones en que puedan incurrir. Así, si no dudan en calificar al personaje de «varón pacífico» (f. 51v), líneas más abajo sorprende su brutalidad en las campañas militares: «... llevando y acabando a sangre y a fuego a los que inquietaban su pueblo» (f. 53v). Se ayuda el retrato de la apologética católica, en este caso determinada por los elementos sobrenaturales que acuden en auxilio del encomiado e interceden en sus victorias militares: la Virgen (f. 53).

Son estos unos retratos donde prima el espíritu combativo, con tintes épicocristianos: la teología a espada y fuego ${ }^{35}$, sancionada por los mismos pontífices,

31 Este es el retrato que de su figura nos deja el libro: «Era de cuerpo y talle gentil, muy bien dispuesto, de rostro grave; para los suyos afable, para los moros severo, de niervos vigorosos, de agilidad grandísima, destreza maravillosa a caballo, y a peón incansable guerrero, asombro de la morisma, fortaleza del cristianismo. Armado a caballo alegraba su ciudad y hacía temblar al enemigo» (f. 54). Para Menéndez Pelayo esta es una semblanza «de fantasía, pero que atestigua la reputación poética tradicional del personaje» (Antología de poetas líricos castellanos. VII. Parte segunda: Tratado de los romances viejos II (Obras completas 1), Madrid, 2012, p. 123).

32 Sus intervenciones militares se desarrollaron entre 1430 y 1440 (Dolores REVENTLOW, La bistoria de la frontera y el romance fronterizo, University of British Columbia, 1976, p. 235). No obstante, al ser un personaje histórico-legendario muchas de sus campañas han sido altamente contaminadas por la tradición fabulosa. Se pueden consultar los estudios de Menéndez Pidal (Poesía popular y romancero, en Revista de Filología Española, 2-3 (1915-16), y Dolores Reventlow al respecto.

33 Documentado ya en el Cancionero de romances de 1547 (Cancionero de romances en que están recopilados la mayor parte de los romances castellanos que fasta agora se han compuesto, Amberes, 1547, f. 175) $\mathrm{y}$ en el de 1550 (Cancionero de romances. Anvers, 1550 [colección de romanceros de los Siglos de Oro, 1], ed. A. Rodríguez Moñino, Madrid, 1967, f. 183).

34 En Historia de los bandos de Zegríes y Abencerrajes (primera parte de las guerras civiles de Granada) (Archivum, 78), ed. Pedro Correa, Granada, 1999. Edición facsímil de la de 1595, p. 165, de Ginés Pérez de Hita. Ambos romances los podemos ver en el Romancero General de Agustín Durán (Romancero General, colección de romances castellanos anteriores al siglo XVIII, recogidos, ordenados, clasificados y anotados por Agustín Durán [BAE, 10], Madrid, 1851), con los números 1047 y 1046, respectivamente.

35 Gonzalo de Zúñiga... «llevando y acabando a sangre y a fuego a los que inquietaban su pueblo. Sus enemigos, en oyendo su nombre, huían dél» (f. $53 \mathrm{v}$ ). 
quienes «dispensaban los homicidios justos de infieles» (f. 53). Estamos en las guerras de religión, donde el rasgo luchador, la valentía ${ }^{36}$, el arrojo de nuestros obispos guerreros medievales adquiere carácter fundamental. No percibimos aquí retratos de gente apacible, humilde, pacífica, como tocaría por sus principios, sino de auténticos héroes, gente de acción, dinámicos, batalladores, inquietos, cuya arma disuasoria, aparte de la palabra, era la espada.

Un segundo grupo lo podría constituir el de aquellos clérigos o prelados que durante la primera mitad del siglo XVI, a partir del pontificado del papa guerrero Julio II (1503-1513), desempeñaron un papel relativamente importante de enlace entre los Estados Pontificios y la corona castellana en una Roma cosmopolita, convertida en auténtico foco de atracción. Destacan en esta dirección el erasmista don Esteban Gabriel Merino (1472-1535, obispo de Jaén entre 1523 y 1535), diplomático y miembro del consejo de Carlos v, que asistió a su coronación en Bolonia (1530); embajador ante el famoso Julio II, protegido de León X, nuncio apostólico de Adriano VI, embajador imperial ante Clemente VII y cardenal de la iglesia romana. Y Gutierre González Doncel (ca. 1468-1527/28? $)^{37}$, protonotario apostólico, familiar y scalcho secreto de León X, entre otros cargos, quien gozó de gran influencia en la corte pontificia entre 1513 y 1521 y desarrolló en su Jaén natal importantes proyectos de reforma eclesiástica $^{38}$.

Al tercer grupo de encomiados podríamos definirlo como de «modelos ejemplares» (siguiendo la terminología de Curtius, op. cit., 242), tipos de personas cuyas trayectorias biográficas destacan sobre todo por la grandeza de su carácter: su nobleza y sus valores espirituales. Este conjunto vendría comandado por una figura de auténtico relieve como san Juan de Ávila (1500-1569) y por sus discípulos Diego Pérez de Valdivia (1525?-1589) y Luis de Noguera (¿-1590).

El humanista baezano Diego Pérez fue catedrático en la universidad de su ciudad, destacando entre los discípulos del Apóstol de Andalucía. Como su maestro, también fue acusado de hereje. Su laudatio es de las pocas que no admite interpolaciones con la descripción de sus obras pías o la reproducción de algunos

36 «Como esta ciudad era frontera, elegíanse obispos animosos de grande esfuerzo y valentía» (f. 53).

37 Los estudios más completos sobre la figura de Gutierre González se deben a M. ${ }^{a}$ Amparo LóPEZ ARANDIA: Rinascimento y Reformatio. El proyecto de Gutierre González en Faén, Jaén, Universidad de Jaén, 2007; y Castellanos y curia romana a inicios del siglo XVI: Gutierre González, en Dimensioni e problemi della ricerca storica, 2 (2005), pp. 55-87.

38 Informaciones estas tomadas del artículo de LÓPEZ ARANDIA, Gutierre González, entre luces y sombras, en Senda de los buertos, 67-68 (1986), pp. 203-218. 
documentos. No existe otro capítulo donde el elogiado coseche mayores elogios. Puede decirse que su vida y obra es la representación ideal de las mejores cualidades que en el concepto de la época podían adornar la figura de un hombre: santidad, honradez, caridad, pobreza, virginidad, inteligencia... En fin, y todo un extenso registro de calificativos que pretenden constituir, junto a su amigo Luis Noguera, el mayor y mejor ejemplo sin mácula que los autores podían exportar como base de su discurso panegirista. Porque no olvidemos que la «guarda y defendimiento» del título hace referencia también a estos prototipos de la Cristiandad que tanto dignifican o ennoblecen la tierra, subrayando la riqueza espiritual de España. La imagen que se ofrece de Diego Pérez es ilustrativa también de ese clima de delación, calumnia, zancadillas, envidia... que propiciaban los tribunales inquisitoriales ${ }^{39}$, y que los autores tienen en tanta consideración porque la justicia sirvió para que sus virtudes todavía resplandecieran con más intensidad. Quizá fuera la injusticia de este calvario lo que más llamó la atención de Ceballos para enmarcar tanto su figura ${ }^{40}$.

Con el mismo estatus de santo que le otorgan los autores, Luis de Noguera (ff. 91v-94v) se presenta como el prototipo de humildad, pobreza («no tenía en su casa otra cosa que algunos libros y una pobre cama»), dadivoso («todo lo que tenía de renta lo daba de limosna»), modestia... casi la perfección. Aunque el retrato debe mucho a la retórica y a la literatura hagiográfica, lo curioso en este caso es la fuente oral de la narración. Y esta se debe a una noble y religiosa carmelita, doña María Mejía, quien conoció personalmente al baezano y cuenta al cronista, arrodillada, sus recuerdos. No resulta extraño el caso, puesto que también era habitual en los textos de la época utilizar la tradición oral como un medio más de difusión de la vida y milagros de los santos, al igual que podían ayudar en su difusión los peregrinos y viajeros ${ }^{41}$.

En ambos casos, nos encontramos con un fuerte vínculo entre el aroma de santidad de los elogiados y su territorio, al cual sacralizan, ennobleciéndolo con sus obras, convirtiendo sus ciudades en espacios simbólico-religiosos; y el pueblo, a su vez, responde transformándolos en objeto de culto: «y se precia esta ciudad de tener las prendas de su venerable cuerpo» (Luis de Noguera, f. 92v). De ahí que los cuerpos-reliquia de estos santos varones llegaron a convertirse

39 Fue encarcelado por la Inquisición en Córdoba por alumbrado, como el maestro Noguera. Ver Juan Manuel SÁNCHEZ GómeZ, Un discípulo del P. Maestro Ávila en la Inquisición de Córdoba. El Dr. Diego Pérez de Valdivia, Catedrático de Baeza, en Hispania, 34 (1949), pp. 104-134.

40 Ver nota 55.

41 Mariana NaVARro, Los santos... [ver n. 22], p. 466. 
en el imaginario de la época en unos «tesoros inestimables para las iglesias y ciudades $\gg^{42}$, convirtiéndose en auténticos lazos de unión con el poder celestial. Además, se sabe de la importancia de la diócesis de Jaén-Baeza en los documentos de la época, por su particular afecto y culto a este tipo de reliquias ${ }^{43}$. Este dato no es menor, porque tal como pone de manifiesto el Discurso de la Langosta, que en el tiempo presente aflige y para el venidero amenaza (Baeza, Pedro de la Cuesta, 1619), de Jiménez Patón, la sociedad católica de la época recurría con naturalidad a los santos como intermediarios ante epidemias, plagas, malas cosechas u otras catástrofes, en forma de procesiones, rogativas o invocaciones varias como remedio a sus males. Se convertían así en importantes elementos catalizadores de la fe.

Advertimos, no obstante, en estos casos de demostraciones épico-cristianas, la mano de los autores una vez más. El elogio exagerado, algo inherente al género, podía acarrear ciertos inconvenientes como el de la tendencia natural a falsear la verdad, asunto este característico también de otros subgéneros panegíricos como la elegía ${ }^{44}$. M. ${ }^{a}$ Amparo López Arandia ${ }^{45}$, en un pormenorizado estudio basado en fuentes historiográficas, pone en duda gran parte de los datos biográficos de Gutierre González. A saber, su origen noble (f. 79 del libro y p. 59 del artículo de López Arandia); su relación con el cardenal Merino, los dos giennenses más influyentes en la corte papal (f. 79v y p. 64, respectivamente); y su enterramiento en la iglesia romana Santiago de los Españoles, hoy Nostra Signora del Sacro Cuore (f. 88v y p. 65). Pero uno de los sucesos más notables de la biografía del clérigo, es el supuesto martirio que sufrió a manos de un «un poderoso enemigo» ${ }^{46}$, durante el Saco de Roma (1527). El apunte es importante porque su gallardía o intrepidez se destaca como una de las virtudes «heroicas» de Gutierre González y porque ha sido tomado como fuente verda-

42 Ibid., p. 469. En la catedral de Jaén se conserva la momia de Alonso Suárez, también conocido como el obispo insepulto. En la catedral de Baeza está enterrado Gonzalo de Zúñiga. Y en Andújar se custodiaron las reliquias de su patrón, san Eufrasio, hasta que con motivo de la invasión musulmana sus restos fueron trasladados a la iglesia de Santa María del Mao (o Valdemao), del monasterio de Samos (Lugo), y algunos de ellos devueltos a su lugar de origen en 1596, originándose así un gran culto.

43 Ibid., pp. 478-479.

44 Francis Cerdan trató la cuestión en un excelente estudio sobre La oración fúnebre del Siglo de Oro, en Criticón, 30 (1985), pp. 78-102.

45 Ver n. 37, 2005, pp. 55-87.

46 Las tropas imperiales, lógicamente, de las que únicamente se indica que eran «los mayores ladrones, los más desacristianados, crueles, sin piedad ni temor de Dios» (f. 87v). 
dera por otros investigadores. Los escritores, sin anunciar fuentes y dentro de la vaguedad cronológica que les caracteriza, se valen del recuerdo o la leyenda para describir los siguientes hechos:

Habiéndole cercado unos y entrado otros, preguntaron por el tesorero de $\mathrm{Su}$ Santidad, y ocurriéndoles nuestro buen doncel les dijo que él era, qué le querían. Ellos, con amenazas impías, le mandaron que les entregasen el tesoro del Papa. A lo cual respondió con toda humildad lo que antes que él había respondido otro nunca vencido español santo y de los primeros mártires, Lorenzo: «El tesoro de Su Santidad está en los pobres». Agraviados los desaforados, disolutos y olvidados de Dios con la modesta respuesta del humildísimo sacerdote comenzaron a dalle empellones diciendo que no estaban para gracias. Y con golpes y malos tratamientos lo llevaron a la sala del tesoro.

Habiendo llegado a ella rompieron los cofres, en los cuales hallaron muy poco, y ofendidos desto con nuevas amenazas le compelían a que les mostrase dónde le había escondido. Y no diciéndoles más de que no había más ni él sabía de otro tesoro ni oro ni plata, le colgaron de las manos y así colgado le daban cruelísimos golpes diciéndole mil baldones y oprobios. A lo cual respondía con indecible paciencia que no sabía de otro tesoro y que el del Sumo Pontífice estaba en los pobres. Y con esto daba muchas alabanzas a Dios y grandísimas gracias diciendo: «Bendito seáis vos, Señor, que os habéis servido de dejarme acabar y poner en el último punto la obra de mi capilla. Ahora llevadme a gozar de vos, cómo y cuándo fuere vuestra voluntad».

A lo cual los despiadados robadores le preguntaron dónde tenía aquella capilla que tanto nombraba, respondiéndoles que en España, en la ciudad de Jaén. Como si les hubiera hecho un grande agravio, le dieron muchos palos con las astas y le colgaron de nuevo de las partes inferiores vergonzosas, diciéndole: «Así morirás santo para que lleven tus huesos a esa tu capilla». Colgado desta suerte con indecible tormento y dolor que sin duda padecía, con la proligedad de la muerte y penetrativo sentimiento estaba pidiendo a Dios que se alargase aquella pena porque tiniéndola en esta vida se escusase de pasalla en la otra. Pedíale que le aumentase los dolores, penas y tormentos y le ayudase con paciencia. [...]

Dejándoselo colgado los inhumanos verdugos impíos, comenzó el psalmo cincuenta del Miserere mei, y en llegando al verso que dice «No apartes de mí tu santo espíritu», dio el alma a su Criador para gozar de su divina vista eternalmente.

Los crueles, algo enternecidos, volvieron y la misericordia que no tuvieron viviendo les compungía. Ya muerto o casi, estándolo descolgando, oyeron que entre dientes dijo tres veces: «Jesús, Jesús, Jesús». Quedó su santo cuerpo tan lastimado que todo él era un espectáculo del cruel martirio que en él se había ejecutado ${ }^{47}$.

47 Ff. 87v-88v. Para la transcripción sigo los criterios modernos, actualizando todo aquello que no afecte a la fonética. Procedo de la misma manera con el resto de citas del artículo. 
Este panegírico relato se inscribe dentro de la tradición literaria sobre el Saco de Roma y en especial sobre la crueldad de un ejército hambriento de botín y las vejaciones sobre la población y la sede pontificia ${ }^{48}$. Puede considerarse, por tanto, un uso literario de un referente histórico sacrificado en aras a la glorificación de un personaje. La adjetivación excesiva más la truculencia o dramatismo de las escenas narradas, abundan en esta dirección.

López Arandia ha cuestionado esta versión, porque si es cierto que Gutierre González murió el 6 de mayo de 1527, día del asalto a los palacios pontificios, como asegura el libro, no puede ser que testara dos semanas más tarde, según documentos cotejados por la investigadora en diferentes archivos (en realidad, el 20 de mayo, según sus averiguaciones, 2005b, 67). Además, parece ser que el clérigo giennense tampoco fue el responsable de custodiar el tesoro vaticano en ese año, cargo que correspondía a Gian Matteo Giberti ${ }^{49}$. Pero recordemos que este tipo de escritores ponían su pluma al servicio de las exageraciones, la retórica, la fraseología panegírica, las metáforas o la iconografía triunfal, además empleaban discutibles fuentes ${ }^{50}$, como constituyentes necesarios para su lenguaje epidíctico o sus propósitos laudatorios. No vamos a insistir más en esta cuestión, ya suficientemente debatida, pero sí voy a detenerme en algunas muestras.

Dentro del estilo grave y del propósito epidíctico para con los retratados, en el plano lingüístico, me interesa resaltar, en primer lugar, la gran cantidad de relaciones elogiosas, probablemente el recurso más abundante. Así, el Papa sobre las buenas cualidades de Gutierre González destaca que: «se agradó de su fidelidad, prontitud, cristiandad y bondad notablemente» (f. 79v). En otras ocasiones, cuando el objeto es sagrado, se multiplica esta retórica, como en estas palabras

48 Ver Antonio RodrígueZ ViLla, Memorias del Saco de Roma: el relato bistórico del asalto y saqueo de Roma en 1527 mediante los documentos de la época (colección Historia/Almuzara), Córdoba, 2011; y, especialmente, el Diálogo de las cosas acaecidas en Roma, de Alfonso de Valdés, Rosa Navarro Durán (ed.), (Letras Hispánicas, 357), Madrid, 1992.

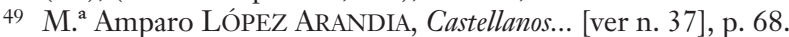

50 Las fuentes de Ceballos son muy peculiares. En muchas ocasiones cita de memoria y equivoca las fechas (fija el nombramiento como obispo de Nicolás de Biedma en 1384, cuando se sabe que murió en 1383, f. 48v; o la muerte de Alonso Suárez en 1522 en vez de en 1520, f. 60) o los nombres; en otras no tiene rubor en mencionar las identidades de los vecinos que le refieren historias, como la procesión celestial de la Virgen de la Capilla (f. $52 \mathrm{v}$ ); de servirse de monjas (f. 92v) o amparándose en unas «personas de mucha verdad y crédito» (f. 89); y en otras disiente abiertamente de lo que dicen otros historiadores ( $«$ Esta historia es muy verdadera y no ha lugar la oposición de Argote de Molina», f. 57). El retrato del maestro Luis de Noguera pertenece casi exclusivamente a la noble María de Mejía, y es tanta la credibilidad de sus palabras que el narrador acaba el capítulo con la siguiente afirmación: «Estas palabras son desta señora, que las dijo sin trocar una. Y así, suplico a quien las leyere la tenga por coronista desta historia» (f. 94). 
sobre la santa faz: «... desta celestial reliquia, desta cara buena, cara de paz, cara de alegría, cara de salud, cara de vida, cara de consuelo, cara de Dios, que es decir de una vez todo lo bueno» (f. 48), como si el objeto loado estuviera por encima de todas las maravillas. El encomio, en este caso, se puede completar con otra suerte de enumeración: la de los conjuntos paralelos. Múltiples son también los paralelismos elogiosos. Alonso Suárez, quien favoreció con sus esfuerzos la construcción del llamado Puente del obispo: «Con estas ansias de buen pastor, con estas ansias de verdadero padre, con este cuidado de prelado santo» (f. $59 \mathrm{v}$ ). El prelado guerrero Nicolás de Biedma, «premiaba virtuosos, castigaba culpados, amparaba a los suyos, era terror y asombro de los enemigos de la fe cristiana» (f. 49).

Otro recurso del lenguaje encomiástico es presentar al retratado probando su superioridad sobre todas las cosas, lo que el filólogo alemán E.R. Curtius denominó sobrepujamiento ${ }^{51}$ : Gonzalo de Zúñiga... «mayor batallador que Julio César» (f. 51v); Diego Pérez... «fue luz del mundo, grande en el reino de los cielos, cumbre de la virtud heroica» (f. 90). Acompaña a este recurso apelativos enfáticos tales como el caritativo, el león español, el asombro de la morisma, el evangélico predicador...; el uso de superlativos: cristianísimo, gloriosísimo, doctísimo y piadosísimo, prudentísimo limosnero, pacientísimo mártir... El encarecimiento se podía completar con las adjetivaciones múltiples o sustantivos enfáticos ${ }^{52}$, que ponderan las cualidades excepcionales de los encomiados.

La laudatio también puede aparecer en forma de apóstrofes o invocaciones. En estos casos se recurre a los ruegos a Dios Todopoderoso, a la Virgen María o a los ángeles. Al obispo Biedma: «Alábante los ángeles, Salvador y Redentor mío, Cristo Jesús, bien de mi alma» (f. 51).

Las comparaciones y las metáforas (hiperbólicas) son también inherentes al discurso encomiástico de los panegiristas. Era frecuente en estos textos que se buscaran comparaciones favorecedoras y analogías que vincularan a los autores con los grandes poetas de la antigüedad. No se trataba de exhibir erudición, tan solo de tomar como referencia a importantes figuras legendarias como Horacio u Homero, por cantar las glorias de los Héctor o Aquiles, para establecer un paralelismo con sus crónicas sobre sus elogiados hombres de fe y provocar las mismas admiraciones. En otros casos los héroes del pasado (Alejandro, David, Numa Pompilio, Julio César) son tomados como términos comparativos para agigantar la figura del elogiado: Gonzalo de Zúñiga es «mayor batallador que

51 «Überbietung», según la terminología de E. R. Curtis, Literatura... [ver n. 9], p. 235.

52 Campos léxicos de la divinización, la virtud, la alegría, el valor, la nobleza, majestad... 
Julio César» (f. 51v); o se recurre a los «planetas» como fuente para sus argumentaciones, como el caso de Juan de Ávila, a quien «llevaron a la Inquisición, de donde salió, como dicen del sol, después de nublado más claro, limpio, puro y hermoso» (f. 97).

También nos encontramos con imágenes que basan su fuerza en ciertos referentes simbólicos. Diego Pérez... «fue sal de la tierra con el ejemplo milagroso de su vida, fue luz del mundo con la dotrina que predicó...» (f. 89v); con metáforas panegíricas a lo divino. Sobe Luis de Noguera: «Toda la ciudad le oía como a santo, y decían muchas personas que cuando predicaba, les parecía que hablaba el Espíritu Santo en él y que sus correciones las hacía Dios a cada uno de por sí dentro de su alma» (f. 93v); o con aposiciones metafóricas: «Era padre de huérfanas, amparo de viudas, arrimo de todos los pobres; era un nivel de vida y costumbres santa» (sobre el mismo padre Noguera, f. 94).

Todo lo referenciado hasta ahora, con otros múltiples ejemplos y categorías, es lo que define este lenguaje hiperbólico, de «mil justas alabanzas» (f. 50), donde los panegeristas innovan escasamente, más bien buscan insertarse en la tradición y asegurarse la efectividad de su texto ${ }^{53}$. Lo cual nos hace notar también algunos ecos de la tradición clásica adaptados a la tierra giennense, tan rica en la hidalguía, distinción y valor de sus prohombres. La literatura de los humanistas se impregna así de una serie de conocidas fórmulas que justifican el ennoblecimiento de la materia tratada o mitifican diferentes cualidades del elogiado. Entre esas buenas cualidades podemos destacar el afecto de los poderosos, protección y amparo (el emperador a Gabriel Merino... «No ha tenido rey tan gran vasallo [...] le respeta como a padre, le ama como a hermano, le pide consejo como a maestro, le estima y honra como agradecido», f. 71). La precocidad virtuosa en la infancia y adolescencia de los encomiados. Diego Pérez... «Siendo de seis años ayunaba tres días en la semana, y creciendo en edad crecía en virtud y mortificación y penitencia» (f. 89), «a los doce años le llamaban el Santo» (f. 91). Intelectual: Gabriel Merino... «A los once esta suficiente en latín y retórica para oír facultad» (f. 63v); militar: «De veinte años fue capitán y cabo de ocho compañías» (f. 64). El amor del pueblo. De Esteban Gabriel Merino, «todo el orbe canta su alabanza»: «los unos por lo bien que lo querían; los otros, por hallarse confundidos en su malicia, le amaban, respetaban, honraban y temían como a la persona misma del emperador. Y decían que tenía un no sé qué que les obligan a todos a un reverencial

53 Emilia García JimÉnEZ, La poesía elegíaca medieval: un discurso epidíctico, en Cuadernos de Investigación Filológica, 19-20 (1994), p. 19. 
respeto» (f. 71). La alegría de la tropa, que acude solícita al requerimiento de los obispos soldados (f. $53 \mathrm{v}$ ). Y, finalmente, las grandes dotes de persuasión que les caracterizan, como en la conversión de infieles del obispo Zúñiga (f. 56).

En otras ocasiones, asistimos a un acercamiento al topos de la divinización, como en los casos en que se confiere esencia cuasi divina a la persona homenajeada. Por ejemplo, cuando en el tormento que padeció, se ponen en boca de Gutierre González las famosas palabras de Cristo en la cruz: «Señor, perdona a estos pobres hombres que no saben lo que hacen» (f. $88 \mathrm{v})^{54}$. O el carácter casi inmortal de la figura de Luis de Noguera y su corpus incorruptus (de «olor y fragancia indecible», f. 93).

A estos consabidos esquemas retóricos, podemos añadir los tópicos que hacen alusión a la retórica de la bumilitas la captatio benevolentiae de los exordios, la brevitas, la pauca e multis o el tópico de lo indecible, entre otros.

Por otro lado, las continuas interrupciones de los narradores en estilo coloquial con la intención de mostrar sus iniciativas, reflexiones, compartir su asombro o conducir al lector de la mano para identificarse con su comunidad, no hacen más que confirmar mis sospechas sobre la autoría del libro. Técnica esta que lo acerca al estilo divulgador más llano y directo de Ordóñez de Ceballos que al más refinado y elegante de un humanista de la talla de Jiménez Patón. Veamos algún ejemplo:

No pienso que le habrá pesado al curioso y devoto letor de que en el capítulo precedente me haya detenido algo más que en los otros dándole recopilada la erudición cristiana que yo he podido juntar con leción cuidadosa acerca del origen y proceso desta celestial reliquia, desta cara buena, cara de paz, cara de alegría, cara de salud, cara de vida, cara de consuelo, cara de Dios, que es decir de una vez todo lo bueno. Y también presumo que estará con deseo de saber cómo vino tanto bien, tal tesoro, tanta felicidad a esta dichosísima ciudad, quién la trajo y por qué camino. Y aunque algunos ponen esto en opinión, yo para mí lo tengo por certeza indubitable (ff. 48$48 v$, sobre Nicolás de Biedma).

$[\ldots]$

Esto es tomadas las cosas por mayor y en junto, mas porque, letor amigo, que gustarás particularmente si eres de los aficionados a nuestra patria de saber algunas cosas con distinción singularizadas, te referiré algunas de las muchas que pudiere y de los muchos papeles que le honrarán y calificarán, que yo he visto repetir algunos pocos. De quien forzosamente inferirás la grandeza deste varón singular como por el tamaño de la mano se conoce lo que es el león todo junto (f. 65, sobre E. Gabriel Merino).

54 Lc 23, 34. 
También es frecuente ver cómo el escritor se introduce en la narración anteponiendo sus circunstancias personales en el devenir de su historia: «Y a mí dame, Señor, gracia para que acierte a servir, perdonándome mis culpas y pecados, que lo harás no acordándote, Señor, de los delitos de mi juventud y de mis ignorancias, sino de tus misericordias, que no tienen número porque son ab eterno» (f. 51).

$\mathrm{Al}$ tiempo, como hemos visto, que el libro se halla repleto de las virtudes de sus protagonistas, también los autores utilizan como argumento la condena de algunos vicios en sus estrategias. Especialmente, queremos aquí hacer notar el de la envidia, quizás como un empeño personal de Ordóñez de Ceballos. Defenderse contra los calumniadores o los peligros de las tentaciones del maligno y del mundo, con el fin de reforzar al elogiado o la grandiosidad de sus empresas es un rasgo común a este tipo de narrativas. Y eso es lo que vemos en varios de los retratos, donde podemos adivinar un correlato de la situación interna de Ceballos en su lucha contra la envidia de sus contemporáneos según su testimonio ${ }^{55}$. Los escritos de Patón que vemos en los preliminares, pueden interpretarse como una ayuda a su amigo. Tanto el prólogo «Al lector» como la carta «Al licenciado don Pedro Ordóñez de Ceballos...» ${ }^{56}$, especialmente esta última, representan una lucha contra uno de los vicios que más sacudían aquella sociedad española. En ellos se carga duramente contra la envidia y los envidiosos.

Las tentaciones de «Satanás, que por mil caminos arma zancadillas y trampas a los justos», sembrando cizaña «en los pechos de aquellos que habían pretendido la dignidad», en caminos repletos de calumnias y falsas acusaciones (sobre el doctor Diego Pérez, f. 90), no es más que el mismo vía crucis de penitencia que tuvo que soportar Ceballos para ser reconocido, para lo que necesitó de la ayuda de su amigo el humanista manchego. En los casos de Diego Pérez y Juan de Ávila, la envidia y calumnias de sus correligionarios hizo que dieran con sus huesos en las cárceles del Santo Oficio. En ambos casos, no obstante, sus vidas quedan salvadas o reforzadas en un apoteósico final: «sacó su virtud más resplan-

55 Testimonio que reproduce Ceballos en su carta a Patón fechada en 1616 y que se reproduce en los preliminares del libro. Las enemistades surgidas de la maledicencia vinieron provocadas por el éxito de sus libros (en especial, su Viaje del Mundo, 1614), por su trayectoria y sus vinculaciones con el poder: «A quién alcanza tantas vitorias tan admirables y dignas de nombre eterno y memoria perdurable ¿por qué se ha de temer que la perturbara la envidia? Antes debe gloriarse en ella como en el toque de fineza de su virtud y prueba de sus hazañas. Y menos le ha de inquietar que sean naturales de su patria los que envidiosos de su fama vomitan la ponzoña» (preliminares, f. XVII). Críticas que debieron de contribuir al agravamiento de su salud, ya deteriorada, y la petición de ayuda a Patón.

56 Ver nota anterior. 
deciente y clara después de los nublados de las calumnias y falsedades. Los padres inquisidores pronunciaron su inocencia y le laurearon en testimonio de su verdad y justicia que había defendido como amigo destas virtudes» (Diego Pérez, f. 90v). En similar tesitura se encontró también el belicoso Nicolás de Biedma.

Finalmente, hay que hacer constar algunas técnicas empleadas en el discurrir narrativo. Una muy característica es interrumpir el hilo de la narración para dar paso a excursos o comentarios que no siempre enriquecen la materia relatada. Estos incisos son a menudo breves, pero en otras ocasiones ocupan varias páginas. La estructura es muy parecida en todos los casos. Se empieza con el elogiado, se interrumpe el panegírico para dar paso al excurso, relacionado con su vida, y finalmente se vuelve sobre la figura para cerrar el capítulo. Así, por ejemplo, de los veintiún folios de la biografía de Gutierre González, solo siete están dedicados a su memoria. Los catorce restantes se dedican a las escuelas de la Santa Capilla de la Iglesia de San Andrés de Jaén, por él fundada en 1615 gracias a sus donaciones, reproduciendo los contenidos de los estatutos de esta santa capilla: proemio, resúmenes de tratados, índice comentado de capítulos. Hecho que no es de extrañar si pensamos que Ordóñez de Ceballos fue alumno de esta institución y debía de conocer de primera mano su funcionamiento ${ }^{57}$. Y la figura del importante clérigo san Juan de Ávila queda reducida a la mínima expresión (de las nueve hojas del capítulo ocupa solo una), en favor de la descripción de la fundación de las Escuelas de Baeza, con la descripción de los edificios, los planes de estudio, la dotación económica o los trabajos de los administradores.

En otras ocasiones se da paso a la inclusión de documentos varios que justifican algún episodio biográfico, como las cartas elogiosas de los reyes o emperadores (ff. 49, 66), de los papas (f. 65v), romances (f. 56), epitafios (ff. 67, 73v); o memoriales de la corona (ff. $67 \mathrm{v}-70$ ). Y en otras, el hilo del relato se ve interrumpido para contar la descripción de alguna famosa procesión, como la del milagro de la Virgen de la Capilla (ff. 52r-v).

\section{AUTORÍA}

Los libros corográficos solían encargarse a humanistas o eruditos locales, capaces de desplegar su habitual arsenal retórico para favorecer sus lugares de origen $^{58}$. He dejado para el final una polémica que acompañó al libro desde su

57 Raúl Manchón, Pedro Ordóñez de Ceballos, Jaén, 2008, p. 21.

58 José Luis PÉREZ PASTOR, Laudes urbis Lucronii: Alabanzas a la ciudad de Logroño en los siglos de oro (1589-1633), en Berceo, 163 (2012), p. 41. 
aparición: su discutida paternidad. Aunque no es el objeto de este estudio debatir sobre tan espinoso asunto, no quisiera dejar pasar la ocasión para aproximarme con unas pinceladas.

Dos son los escritores que la crítica ${ }^{59}$ ha discutido, aunque entre ellos no consta que hubiera disputa alguna, más bien al contrario. La polémica surgió sobre todo por aparecer solo el nombre del Maestro de Villanueva de los Infantes al frente de la portada original, motivo por el cual las más de las veces se le ha distinguido con ese mérito. En menos ocasiones, sin embargo, ha circulado con el nombre del clérigo aventurero giennense ${ }^{60}$ Pedro Ordóñez de Ceballos ( $c a$ 15561635), al que considero verdadero autor; $y$, por último, en algunos estudios, los menos, se apunta hacia la doble paternidad.

En primer lugar, a nombre de Patón encontramos la portada del libro, la Licencia y la Aprobación (estas dos últimas de 1624). Y a nombre de los dos la Tasa (1628), la Suma del Privilegio (1624) y la Dedicatoria al marqués de Bedmar, por el hijo de Patón (sin fechar). A primera vista resulta un tanto confuso la falta de una autoría definida en los preliminares más preceptivos del libro. No obstante, en la tabla de contenidos (ff. VIII-IX) ya percibimos que hay un primer autor, y que este es Ordóñez de Ceballos, por la biografía que le dedicó Patón: «Del famoso varón, primer autor desta historia» (cap. 37, ff. 201-215v). En el prólogo «Al lector», además, el manchego zanja la cuestión en sus primeras líneas: «Para que no te canses, lector, en adivinar el porqué la obra prometida y comenzada por otro la haya proseguido yo y dándole el fin que he podido, contaré el suceso cómo pasa». La autoría primera, pues, según Patón, es indiscutible: corresponde a Ceballos la mayoría de los contenidos, y al manchego la continuación de algunos y el papel de supervisor ${ }^{61}$.

59 Habitualmente copiando datos de estudios o citas anteriores pero sin cotejar los contenidos.

$60 \mathrm{O}$ «sacerdote-soldado», tal como lo define su amigo Patón en el libro. Hay semblanza biográfica por Raúl MANCHÓN GÓMEZ en Pedro Ordóñez de Ceballos. Vida y obra de un aventurero que dio vuelta y media al mundo, Jaén, Universidad de Jaén, 2008; y en Miguel Zugasti, «El jiennense Pedro Ordóñez de Ceballos: aventurero, soldado, viajero, comerciante, misionero, héroe de comedia... y también dramaturgo», en Elisa García-Lara, Antonio Serrano (eds.), Dramaturgos y espacios teatrales andaluces de los siglos XVI-XVII: actas de las XXVI fornadas de Teatro del Siglo de Oro del 28 al 31 de marzo de 2009. Almería (colección Letras, 57), Almería, 2011, pp. 157-173.

$61 \mathrm{Al}$ final de los preliminares del libro, además, consta un grabado con la imagen de Ceballos escribiendo, que repite en otros libros suyos como los Cuarenta triunfos de la santísima Cruz de Cristo N. S. y Maestro, Madrid, 1614, o el Tratado de las relaciones verdaderas de los reinos de la China, Cochinchina y Champaá y otras cosas notables y varios sucesos, sacadas de sus originales, Jaén, 1628, a modo de «certificado de autenticidad». Es el único retrato conservado del autor, y en él se ilustra su doble condición de clérigo y de soldado. 
Los motivos de la colaboración son dos, y los explica el ayudante en su prólogo: la mala salud de Ceballos ${ }^{62}$ y la envidia de sus contemporáneos. Aunque ambos tienen su importancia en la futura alianza de ingenios, en la elección de Patón debió de sopesar seriamente su admiración por un tratado sobre la Santa Cruz del andaluz y, sobre todo, ciertas críticas vertidas contra su anterior libro, el Viaje del mundo (1614), tachado por algunos de sus contemporáneos de fantasioso e inverosímil y poco menos que mentiroso ${ }^{63}$. En carta fechada el 30 de setiembre de 1616, que se reproduce en el prólogo «Al maestro Bartolomé Jiménez Patón», además de los achaques de salud, manifiesta su desazón por la recepción de sus proyectos, que casi le llevan al abandono: «no puedo negarle que la envidia de algunos ánimos casi me hiciera detener en ellos, mas esta con algunas consideraciones la he vencido» (f. XIX).

Así las cosas, en el prólogo de Patón «Al licenciado Pedro Ordóñez de Ceballos», este sale en defensa de su colega con todo un discurso sobre la envidia, concluyendo con que «las murmuraciones de los que hoy viven no me inquietan, que unos por amor y otros por odio, te apartan de lo justo» (f. XXI). Insinúa de esta manera que fue más «la fuerza de los envidiosos» que no la «poca salud»los problemas por los que pasó su solicitante.

Así, pues, y resumiendo, un escritor impelido, enfermo, con uno de sus proyectos más ambiciosos, le encarga a un reputado escritor al que admira que tenga a bien revisarlo y concluirlo en aquello que considere necesario: «tome esta obra por su cuenta y así en acaballa como en perficionar lo hecho ponga algún trabajo

62 Según descubrimos en su biografía llegó a estar más diez meses en cama sin poder levantarse (cap. 37). La mala salud del andaluz es una constante que le acompaña desde su regreso a España (1604), después de dar la vuelta al mundo, hasta su muerte (1635). No es un tópico literario. Sobre el asunto puede consultarse a MANCHÓN GÓMEZ, 2008, pp. 70-80.

63 Críticas que conocemos a partir del testimonio de José MARTíneZ DE MAZAS (1731-1805): «Padeció varias censuras poco benignas de sus Relaciones y Viaje del mundo, y modernamente el P. Isla le puso en ridículo» [...] «Yo no juzgo que él fuese un viajero mentiroso...» (Retrato al natural de la ciudad y término de faén, su estado antiguo y moderno, con demostración de cuanto necesita mejorarse su población, agricultura y comercio / por un Individuo de la Sociedad Patrística de la dicha ciudad..., Jaén, 1794, pp. 9 y 10, respectivamente). Modernamente, las críticas han continuado: Manuel SERRANO Y SANZ: «difícil es averiguar cuánto hay de verídico y cuánto de fabuloso» («Introducción» a su edición del Viaje del mundo (NBAE, 2), Madrid, 1905, pp. XCII-XCIV); Juan L. ALBORG: «No cabe duda de que algunos de los episodios contados por Ordóñez son sospechosos en sí mismos» («Prólogo» a su edición del Viaje del mundo, Madrid, 1957, 75-76). Comentarios similares en Emiliano Jos, Centenario del Amazonas: La expedición de Orellana y sus problemas históricos. Fuentes y bibliografía, en Revista de Indias, IV, 11 (1943), pp. 15; e Ignacio B. ANZOÁteguI, «Prólogo» a su edición del Viaje del mundo, Buenos Aires, 1947, p. 12. 
honrando el mío» ${ }^{64}$. El manchego acepta las explicaciones del clérigo y el reto «más con deseo de agradar que con esperanzas de dalle la perfeción que la obra y principios piden», mostrando su interés («la quiero tomar -la Historia de faénpara dilatarla en lo que me fuere posible»).

Pero, ¿en qué consistió en realidad el trabajo del ilustre humanista? Después de una atenta lectura mi parecer es que Ceballos buscó la intervención de un humanista relevante a partir del momento en que su quebrantada salud le impidió continuar con su redacción. Por ese motivo, considero que Patón se centró básicamente en el último tercio del libro, concretamente a partir del capítulo 37 (de 46), con el inicio emblemático de la biografía del que ya consideraba su amigo, continuando con la parte más corográfica del antiguo reino de Jaén (últimos nueve capítulos); sin que esto le impidiera introducir algunos cambios en el manuscrito entregado, actualizando datos o mejorando su estilo en el borrador que le pasó Ceballos. En ese capítulo se ofrecen dos datos importantes según mi opinión. En las primeras líneas el autor recuerda la población de Almedina, «mi patria», despejando así toda duda sobre su posible autoría. Más abajo, la fecha de 1627, cuando el rey Felipe IV confirmó los privilegios del castillo-Alcázar de Jaén a súplica de su visitador de castillos, Salvador Caro de Rojas ${ }^{65}$, demuestra que Patón siguió trabajando en su cometido hasta unos meses antes de la impresión (mayo de 1628), a pesar de que los preceptos legales de los preliminares están fechados en 1624 (entre junio y septiembre).

\section{CONCLUSIÓN}

El análisis realizado en este artículo permite concluir que los encomios de clérigos realizados en la Historia de faén, de Ordóñez de Ceballos y Jiménez $\mathrm{Pa}$ tón, se insertan en una organización análoga a la de otros discursos del mismo

64 Preliminares sin numerar. Ceballos también buscó el amparo de Patón en su Tratado de las relaciones verdaderas de los reinos de la China, Cochinchina y Champaá, y otras cosas notables y varios sucesos, sacadas de sus originales, Jaén, Pedro de la Cuesta, 1628, a quien le dedica el libro en un prólogo «Al elocuentísimo maestro Bartolomé Jiménez Patón» firmado por un «Capellán indigno y verdadero amigo de v.m.».

65 Cédula de Su Majestad en favor de Salvador Caro, capitán de la artillería y soldados que sirven la defensa, guarda y velas de los alcázares reales, castillos y fortalezas deste reino y muy noble, famosa y leal ciudad de Faén, guarda y defendimiento de los reinos de Castilla. Jaén, Pedro de la Cuesta, a costa de Salvador Caro de Rojas, 1627. Términos que vemos hoy como lema del escudo de Jaén: «Muy noble y muy leal ciudad de Jaén, guarda y defendimiento de los reinos de Castilla», que los autores aprovecharon para el título de la obra. 
género epidíctico. La narración de este tipo de composiciones y el ánimo de influir en el oyente determina el uso de un lenguaje hiperbólico y de toda una serie de técnicas tomadas de las retóricas clásicas de Quintiliano, Cicerón y Menandro el Rétor.

La confluencia de los retratos encomiásticos de ilustres varones giennenses con la corografía en la que se inserta el libro, también delimita su cauce creativo. En este caso, la laus civitatis y el elogio cristiano sirven para mitificar un territorio al tiempo que lo inserta en esa cultura de signo providencialista de la España del siglo XVII bajo la sombra de la Contrarreforma. 